\title{
Obtaining and application of some homoisoflavonoids
}

\section{Abstract}

Although there are recent advances for the understanding of many diseases, even man has the need to search for new agents that help to control or eradicate them. In the present mini-review, the synthetic obtaining of some homoisoflavonoids and the possible applications that these compounds can obtain in the area of medicine are reported.

Keywords: synthesis, homoisoflavonoids, medicine
Volume 7 Issue 5 - 2018

\section{Núñez Jesús}

Department of Biology, University "Clodosbaldo Russian", Venezuela

Correspondence: Núñez Jesús, Department of Biology, University “Clodosbaldo Russian”, Cumaná,Venezuela, Tel +582934672I38,Email jnunez@uptos.edu.ve, jesusbnr@gmail. com

Received: October 4, 2018 | Published: October 05, 2018

\section{Introduction}

The homoisoflavonoids have a structure constituted by carbon atoms which consists of a group such as chromone, chromanone or chromana and a benzyl or benzylidene group attached to carbon (Figure 1).

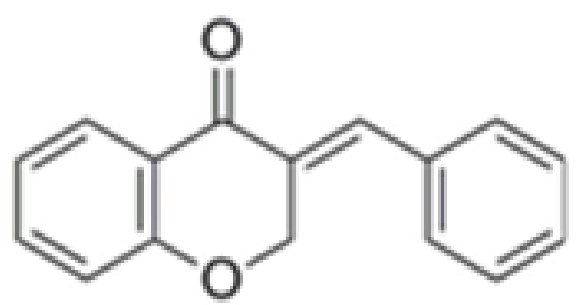

Figure I Structure of homoiso flavonoid.

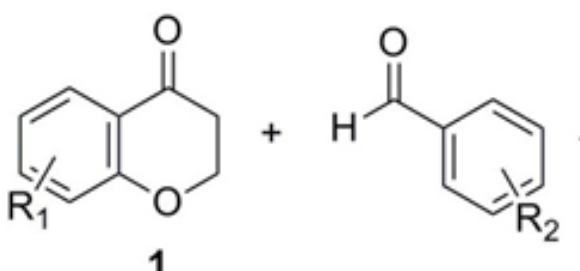

One of the few methods reported in the literature for the synthesis of these compounds is based on the use of bases. Brien et al., ${ }^{9}$ synthesized them by reacting the benzochromanone with an aldehyde
Homoisoflavonoids, derivatives of 3-benzylchrom-4-ones, are constitutionally derived from 1,2-diphenylpropane. They comprise a small family of natural polyphenolics related to flavonoids1. Homoisoflavonoids are distributed in many species of the Liliaceae family (Eucomis bicolor, ${ }^{1}$ Ophiopogon japonicas, ${ }^{2}$ Muscari racemosum,,${ }^{1,3}$ Cremastra appendiculata, ${ }^{4}$ and Veltheimia viridifolia ${ }^{5}$ ) and several other plant species (e.g., Dracaena cinnabari ${ }^{6,7}$ and Caesalpinia sappan $^{8}$ ).

Considering above and existence the great interest in synthesis of important pharmacological active heterocycles, the synthesis of homoisoflavonoids has also attracted the interest of chemists and pharmaceutics.

Synthesis of some homoisoflavonoids.

The usual method for synthesizing (E)-3-benzylidenechroman4-ones 2 is based on the condensation of Croman-4-one $\mathbf{1}$ with an aromatic aldehyde in the presence of an acid in catalytic amounts.<smiles>O=C1CCOc2ccc3ccccc3c21</smiles><smiles>[R]c1c([R4])c([R])c(C=O)c([R])c1[R]</smiles><smiles>O=[N+]([O-])O[Na]</smiles><smiles>[R]c1c([R4])c([R])c(/C=C2\COc3ccc4ccccc4c3C2=O)c([R1])c1[R]</smiles>

in ethanol at room temperature $10-12 \mathrm{~h}$, using $10 \%$ aqueous sodium hydroxide as shown.

Acid<smiles>[R][R]c1ccccc1/C=C1\COc2ccccc2C1=O</smiles>

2 
The piperidine is another base used for the synthesis of homoisoflavonoids. $^{10}$ Lévai et al., ${ }^{11}$ synthesized a serie of 3-benzylidene chroman-4-ones $(\mathrm{X}=\mathrm{O})$ and 3-benzylidentiochroman- 4-ones $(\mathrm{X}=\mathrm{S})$ by mixing equimolar amounts of chroman-4-ones $(\mathrm{X}=\mathrm{O})$ or thiochroman-4-ones $(\mathrm{X}=\mathrm{S})$ with the corresponding aromatic aldehyde and few drops of piperidine under reflux.<smiles>[X]c1ccc(C=O)cc1</smiles>

It has sometimes been observed that one of the two hydrogen atoms that is located in the beta position $\beta$ in the thiopyranone ring migrates to the carbon atom that is in the beta $\beta$ position of the double bond $\mathrm{C}=\mathrm{C}$ exocyclic, to give rise to an isomer compound as shown below:

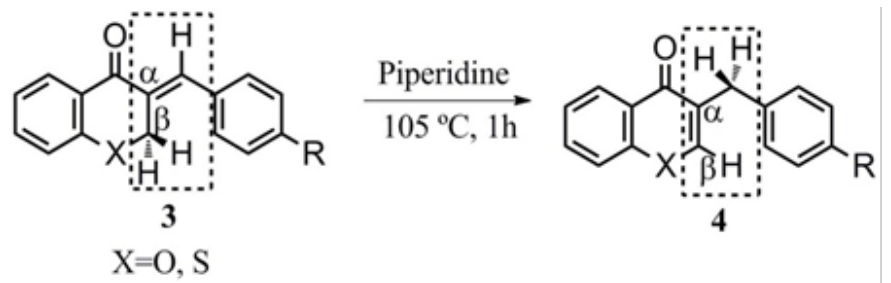

Our research group recently showed through computational calculations that the migration of any of the hydrogen atoms that locate in beta position $\beta$ in the ring thiopyran-4-one 3, can occur regardless of whether this atom is in axial or equatorial position in the ring 4. Each of these hydrogen atoms shows the same activation energy during displacement. The transition state of the rearrangement showed a structure with a ring of four members and a folding of $124^{\circ}$ (Figure 2). ${ }^{12}$

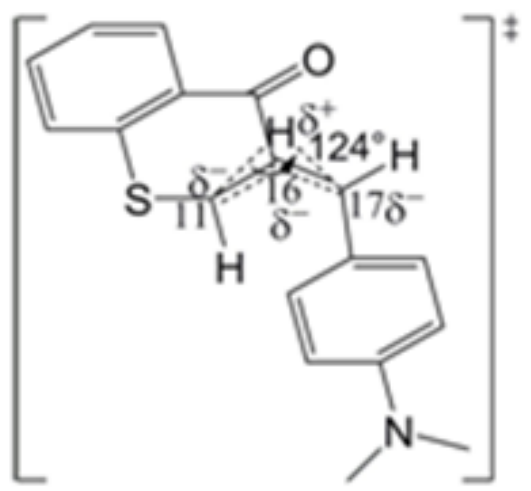

Figure 2 Structure for the transition state of (Z)-3-(4-(Dimethylamino) benzylidene)_thiochroman-4-one.

\section{Applications of some homoisoflavonoids}

Some isolated or synthetic homoisoflavonoids, different biological properties such as: anti-inflammatory, ${ }^{13}$ antiproliferative 10 , antifungal, ${ }^{14-16}$ antioxidant, ${ }^{17,18}$ antiviral, ${ }^{19}$ anticancer drugs ${ }^{20,21}$ and as inhibitors of HIV-1. ${ }^{22,23}$ Studies of structure-activity relationship have revealed that the volume, electronic density and steric hindrance of these compounds are parameters that are related to their antiinflammatory activity. ${ }^{24}$ Another study states that the interaction energy and the electrostatic potential are descriptors of antibacterial activity, where these compounds show the ability to bind to a receptor or a macromolecule..$^{25}$

\section{Acknowledgements}

None.

\section{Conflict of interest}

The author declares that there is no conflict of interest.

\section{References}

1. Heller W, Tamm C. Fortschr Chem Org Naturst. 1981;40:106.

2. Chang M, Shen CC, Huang Y, et al. Five New Homoisoflavonoids from the Tuber of Ophiopogon japonicus. J Nat Prod. 2000;65(11):1731.

3. Juránek I, Suchý V, Stará D, et al. Pharmazie. 1993;48:310.

4. Shim JS, Kim JH, Lee J, et al. Anti-Angiogenic Activity of a Homoisoflavanone from cremastra appendiculata. Planta Med. 2004;70(2):171-173.

5. Amschler G, Frahm AW, Hatzelmann A, et al. Constituents of veltheimia viridifolia; I. Homoisoflavanones of the bulbs. Planta Med. 1996;62(6):534.

6. Juránek I, Suchý V, Stará D, et al. Pharmazie. 1993;48:310

7. Machala M, Kubínová R, Horavová P, et al. Chemoprotective potentials of homoisoflavonoids and chalcones of Dracaena cinnabari: modulations of drug-metabolizing enzymes and antioxidant activity. Phytother Res. 2001;15(2):114.

8. Niranjan Reddy VL, Ravikanth V, Jansi Lakshmi VV, et al. Inhibitory activity of homoisoflavonoids from Caesalpinia sappan against Beauveria bassiana. Fitoterapia. 2003;74(6):600-602.

9. Brien KA, Bandi RK, Behera AK, et al. Design, synthesis and cytotoxicity of novel chalcone analogs derived from 1-cyclohexylpyrrolidin-2-one and 2,3-dihydrobenzo[f]chromen-1-one. Arch Pharm Chem Life Sci. 2012;345(5):1-8.

10. Perjési P, Das U, Clercq ED, et al. Design, synthesis and antiproliferative activity of some 3-benzylidene-2,3-dihydro-1-benzopyran-4-ones which display selective toxicity for malignant cells. Eur. J. Med. Chem. 2008;43(4):839-845.

11. Lévai A, Schág JB. Synthesis of 3-benzylidenechroman-4-ones and -1-thiochroman-4-ones. Pharmazie. 1979;34:749. 
12. Nuñez J, Márquez E, Rivas C, et al. Estudio computacional del rearreglo sigmatrópico $[1,3]$ de la (Z)-3-(4-(dimetilamino)benciliden)tiocroman-4ona. Avances en química. 2017;12(2-3):23-30.

13. Hung TM, Thu CV, Dat NT, et al. Homoisoflavonoid derivatives from the roots of Ophiopogon japonicas and their in vitro anti-inflammation activity. Bioorg Med Chem Lett. 2010;20(8):2412-2416.

14. Das B, Thirupathi P, Ravikanth B, et al. Isolation, synthesis and bioactivity of homoisoflavonoids from Caesalpinia pulcherrima. Chem Pharm Bull. 2009;57(10):1139-1141.

15. Al Nakib T, Bezjak V, Meegan MJ, et al. Synthesis and antifungal activity of some 3-benzylidenechroman-4-ones, 3-benzylidenethiochroman-4ones and 2-benzylidene-1-tetralones. Eur J Med Chem. 1990;25(5):455462.

16. Fang B, Ma Z, Yang G, et al. Synthesis and antifungal activity of (Z)-3 (bromomethylene)thiochroman-4-ones. Int J Chem. 2010;2(1):143-146.

17. Siddaiah V, Maheswara M, Rao CV, et al. Synthesis, structural revision, and antioxidant activities of antimutagenic homoisoflavonoids from Hoffmanosseggia intricate. Bioorg Med Chem Lett. 2007;17(5):1288-1290 .

18. Li Y-F, Liu Z-Q, Luo X-Y. Properties of synthetic homoisoflavonoids to reduce oxidants and to protect linoleic acid and DNA against oxidation. $J$ Agric Food Chem. 2010;58(7):4126-4131.
19. Tait S, Salvati AL, Desideri N, et al. Antiviral activity of substituted homoisoflavonoids on enteroviruses. Antiviral Res. 2006;72(3):252-255.

20. Nguyen AT, Fontaine J, Malonne H, et al. Homoisoflavanones from Disporopsis. Phytochemistry. 2006;67(19):2159-2163.

21. Tang Y, Yu B, Hu J, et al. Three new homoisoflavanone glycosides from the bulbs of Ornithogalum caudatum. J Nat Prod. 2002;65(2):218-220.

22. Ishikawa T, Oku Y, Tanaka T, et al. An approach to anti-HIV-1 active Calophyllum coumarin synthesys: An enantioselective construction of 2,3-dimethyl-4-chromanone ring by quinine-assited intramolecular Michael-type addition. Tetrahedron Lett. 1999;40(19):3777-3780.

23. Xu Z-Q, Buckheit Jr. RW, Stup TL, et al. In vitro anti-human immunodeficiency virus (HIV) activity of the chromanone derivative, 12-oxocalanolide A, a novel NNRTI. Bioorg Med Chem Lett. 1998;8(16):2179-2184

24. Du Toit K, Elgorashi EE, Malan SF, et al. Anti-inflammatory activity and QSAR studies of compounds isolated from Hyacinthaceae species and Tachiadenus longiflorus Griseb. (Gentianaceae). Bioorg Med Chem. 2005;13(7):2561-2568.

25. Du Toit K, Elgorashi EE, Malan SF, et al. Antibacterial activity and QSAR of homoisoflavanones isolated from six Hyacinthaceae species. $S$ Afr $J$ Bot. 2007;73(2):236-241 